УДК $338.43: 316.422$

DOI: $10.15673 /$ fie.v11i1.1293

\author{
Нікішина О.В. \\ доктор економічних наук, старший науковий співробітник \\ E-mail: ksenkych@gmail.com \\ ORCID ID: 0000-0002-7172-3551 \\ Муратов О.M. \\ кандидат економічних наук, здобувач \\ відділ ринкових механізмів та структур \\ Інститут проблем ринку та економіко-екологічних досліджень НАН України \\ Французький бульвар, 29, м. Одеса, Україна, 65044 \\ E-mail:omuratov45@gmail.com \\ ORCID ID: 0000-0001-5148-4189
}

\title{
ВІДТВОРЮВАЛЬНИЙ МЕХАНІЗМ СТИМУЛЮВАННЯ РОЗВИТКУ УКРАЇНСЬКОГО РИНКУ ОРГАНІЧНОЇ ПРОДУКЦІЇ
}

У статті обґрунтовано сутність та складові відтворювального механізму стимулювання розвитку вітчизняного органічного ринку. Досліджено взаємопов'язаність інституційних заходів підтримки органічного виробництва у площині забезпечення розширеного відтворення ресурсів у секторах ринку та формування внутрішнього попиту на органічну сировину. Проведено оцінку пов'язаних проблем відтворювального розвитку суб'єктів внутрішнього ринку органічної продукції, зокрема, індивідуальних аграрних господарств і підприємств із виробництва продуктів дитячого харчування. Зроблено висновок про те, що становлення вітчизняного органічного ринку відбувається на основі сировинної моделі розвитку аграрного ринку із фрормуванням типових структурних дисбалансів, притаманних ринку неорганічної аграрної продукції. Доведено доцільність розробки та впровадження відтворювального механізму стимулювання розвитку вітчизняного ринку органічної продукції на базі європейської практики, адаптованої до українських реалій. Обґрунтовано цільові орієнтири, систему принципів, компонентів та очікуваних ефектів відтворювального механізму стимулювання розвитку органічного ринку України. Показано його зв'язок із становленням основ інклюзивної «зеленої» економіки.

Ключові слова: ринок, органічна продукція, відтворювальний механізм, інститути, суб'єкти ринку, зв'язки, інклюзивність, заходи державної підтримки.

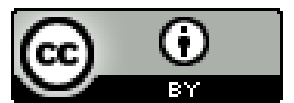

This work is licensed under a Creative Commons Attribution 4.0 International License http://creativecommons.org/licenses/by/4.0/
Постановка проблеми та її зв'язок з важливими науковими та практичними завданнями. Сучасний вектор державної агропродовольчої політики характеризується активізацією програм національної адаптації Цілей сталого розвитку. Вони визначають спрямування регуляторних заходів на подолання бідності, забезпечення зайнятості й добробуту населення, захист навколишнього середовища тощо. У цьому контексті вагомого значення набуває розробка відтворювальних механізмів стимулювання розвитку агропродовольчих ринків, у т.ч. органічних, оскільки, на нашу думку, саме такі механізми спроможні найбільш ефективно впроваджувати Цілі сталого розвитку в Україні, забезпечити включення найменш захищених суб'єктів, зокрема фермерських i особистих селянських господарств, в ринковий процес відтворення на засадах узгодження інтересів усіх його учасників та держави.

Сьогодні в Україні вже існує законодавча ініціатива, яку можна вважати кроком до сталого відтворювального розвитку агропродовольчих ринків. Так, Стратегія розвитку аграрного сектору економіки на період до 2020 року № 806-р від 17.11.2013 р. [1] актуалізує завдання сприяння розвитку органічного землеробства, насамперед в особистих селянських $\mathrm{i}$ середніх господарствах. Очікувані результати від впровадження Стратегії передбачають, зокрема, розширення площі виробництва органічної продукції та сировини, збільшення обсягів виробництва продукції дитячого харчування на $9 \%$, зменшення рівня бідності населення у сільській місцевості. Відтак, головні положення Стратегії [1] формують нові економікоекологічні пріоритети агропродовольчої політики, зокрема, стимулювання переробки органічної агропродукції, розвиток вітчизняного виробництва продукції дитячого харчування, залучення малих суб'єктів господарювання до органічного сектору, як засіб підвищення їх економічної ефективності.

3 іншого боку, цільова орієнтація Стратегії на зменшення рівня бідності сільського населення, підтримку малих форм господарювання вказує на ii iнклюзивність, що відповідає Цілям сталого розвитку та концепції інклюзивної «зеленої» економіки. Ринкову інклюзію (англ. inclusion - включення, залученість), на нашу думку, можна трактувати як збільшення ступеню участі суб'єктів господарювання, 
зокрема малих і середніх, у процесі відтворення, формування рівноправних відносин і взаємодій між ними, об'єктивний перерозподіл доходів між секторами ринку для їх відтворювального розвитку. Впровадження ринкової інклюзії передбачає перехід від екстрактивних інститутів (англ. to extract - «витягувати»), орієнтованих на перерозподіл доходів на користь обмеженого кола суб'єктів, до інклюзивних інститутів. Саме дослідженню останніх на базі відтворювального підходу присвячена стаття.

Аналіз останніх публікацій по проблемі. Теоретико-методологічні засади регулювання розвитку ринку органічної продукції висвітлені в працях учених Н. М. Андрєєвої [2], Б. В. Буркинського [3], А. В. Вдовиченко [4], В. Г. Грановської [5], Н.В. Зіновчука, Ю.С. Кирилова, Л.С. Купінець, Є.В. Мішеніна, Л.О. Мармуль [6] та інших науковців. Водночас додаткових досліджень потребує питання обгрунтування відтворювального підходу до формування та впровадження інклюзивного механізму стимулювання розвитку вітчизняного ринку органічної продукції для його збалансованого розвитку та нарощування обсягів продукування ринкової доданої вартості в умовах глобалізації.

Формулювання цілей дослідження. Мета статті - теоретичне обгрунтування й розробка відтворювального механізму стимулювання розвитку українського ринку органічної продукції - окреслила низку завдань:

1) дослідження взаємопов'язаності інституційних заходів підтримки органічного виробництва на базі відтворювального підходу;

2) оцінка множини пов'язаних проблем відтворювального розвитку суб' єктів внутрішнього ринку органічної продукції;

3) обгрунтування цільових орієнтирів, принципів, компонентів та очікуваних ефектів відтворювального механізму стимулювання розвитку органічного ринку України.

Виклад основних результатів та їх обгрунтування. Закон України «Про основні принципи та вимоги до органічного виробництва, обігу та маркування органічної продукції» № 2496-VII від 10.07.2018 р. [7] визначає органічну продукцію як сільськогосподарську продукцію, у т. ч. харчові продукти та корми, отримані в результаті органічного виробництва. При цьому органічне виробництво трактується як сертифікована діяльність, пов'язана 3 виробництвом сільськогосподарської продукції (всі стадії технологічного процесу), що провадиться із дотриманням вимог законодавства у сфері органічного виробництва, обігу та маркування органічної продукції. Відтак, органічне виробництво охоплює всі ланки виробничо-логістичного ланцюга, а термін «органічна продукція» включає як сировину, так і продукти переробки з високою доданою вартістю.

Серед принципів, на яких базується державна політика у сфері виробництва, обігу та маркування органічної продукції, задекларовано принцип сталого розвитку та принцип взаємоузгодженості економічних інтересів операторів, суспільства і держави (ст. 6) [7]. Вказані принципи інтегрують інституційні новов- ведення у координати сталого розвитку та інклюзивного «зеленого» зростання, що стимулюватиме впровадження Цілей сталого розвитку в Україні.

До «вузьких» місць у Законі України «Про основні принципи та вимоги до органічного виробництва, обігу та маркування органічної продукції», на нашу думку, доцільно віднести відсутність чітко визначених механізмів $і$ форм взаємодії держави й суб'єктів ринку органічної продукиії. Поза увагою законодавчого акту залишились механізми державної підтримки органічних виробництв в Україні. У ст. 8 даного Закону уточнюється, що «державна підтримка може надаватися операторам у рамках загальнодержавних та регіональних програм за рахунок і в межах видатків за бюджетними програмами, спрямованими на підтримку розвитку сільськогосподарських товаровиробників» [7]. На наш погляд, положення цієї статті $є$ надзвичайно загальними та декларативними. Адже вони не визначають ні форми, ні змісту взаємодії держави й суб'єктів ринку органічної продукції.

Імплементація передового світового досвіду щодо стимулювання розвитку органічного сільського господарства у вітчизняну систему господарювання повинна базуватись на узгодженості положень головних формальних інститутів, що декларують відтворювальний розвиток органічного виробництва в Україні, та орієнтуватися на одночасне вирішення ключових проблем розвитку суб'єктів не однієї, а декількох ланок виробничо-логістичного ланцюга певного органічного товару, шляхом розробки та впровадження системних селективних заходів державного впливу.

Проведені дослідження дозволили обгрунтувати взаємопов'язаність положень головних інклюзивних інститутів у сфері органічного виробництва, орієнтованих на вирішення проблем відтворювального розвитку потенційних суб'єктів внутрішнього ринку органічної продукції (рис. 1).

Стратегія розвитку аграрного сектору економіки на період до 2020 року № 806-р від 17.11.2013 р. [1] одним із принципів розвитку аграрного сектору визначає розвиток різних форм господарювання за умови пріоритетності формування господарств, що мають велику соціально-економічну роль для сільських громад. До таких форм віднесено фермерські й особисті селянські господарства, що формують індивідуальний сектор аграрного ринку. На практиці відбувається процес відторгнення індивідуальних господарств від ринкової інфраструктури, витіснення їх великими корпоративними структурами у сегменти виробництва малорентабельних, але трудомістких i соціально значимих видів продукції.

Проведений аналіз свідчить, що корпоративний сектор виробляє 63,3\% зернових і 67,3\% олійних культур, 88,2 \% цукрових буряків і 61,5 \% м'яса в країні (табл.1).

Водночас господарства населення продукують 98,1 \% картоплі, 85,5 \% овочевих культур, 83,7 \% плодово-ягідних культур і 73,1\% молока в країні. Фермерські господарства (у залежності від розміру) займають певні ніші у виробництві різних видів агропродукції. 
Положення інклюзивних інститутів, орієнтованих на вирішення проблем суб'єктів ринку

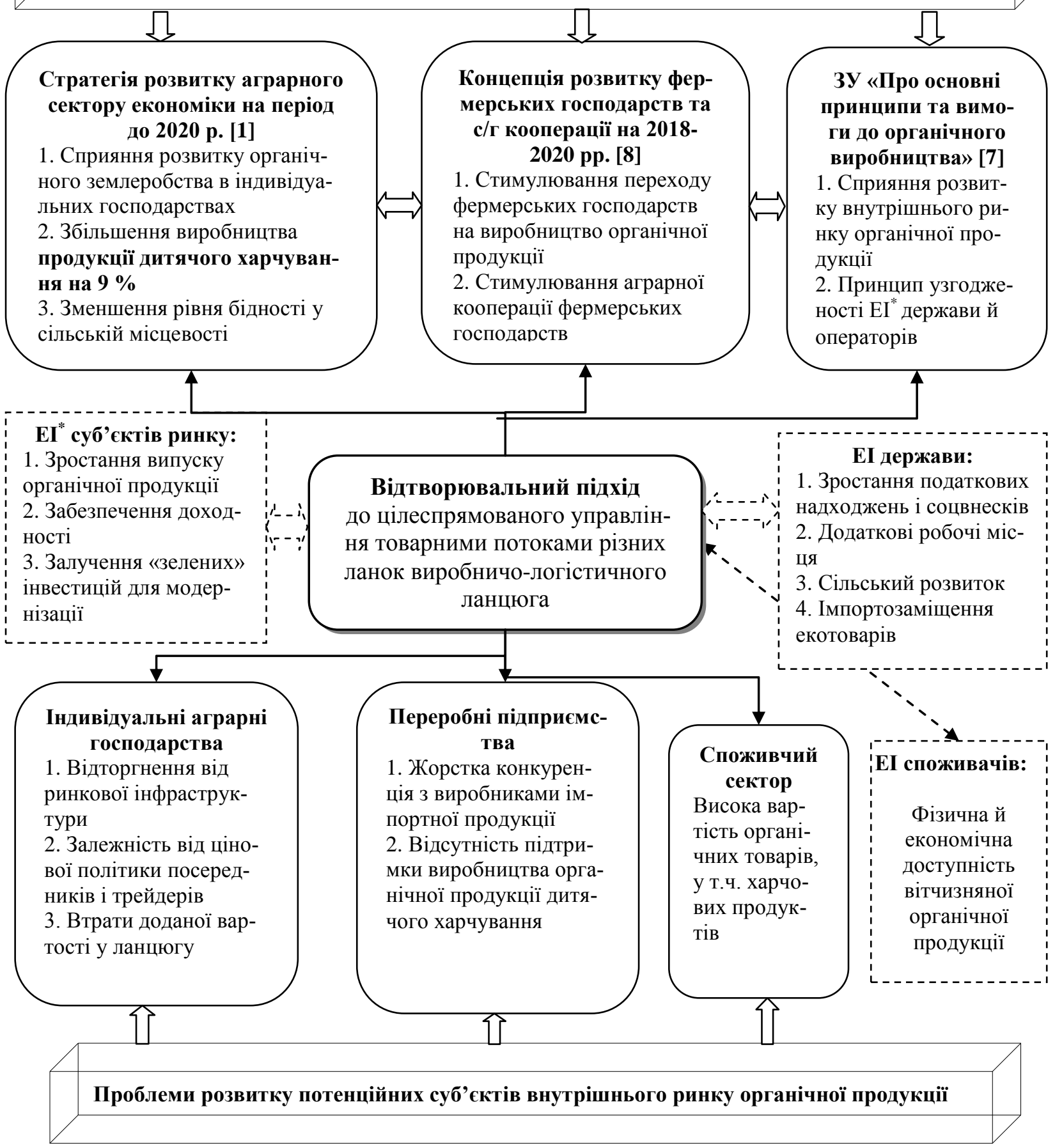

*Умовні позначення: EI - економічні інтереси

Рис. 1. Взасмопов'язаність положень головних інклюзивних інститутів, орієнтованих на вирішення проблем відтворювального розвитку потенційних суб'сктів внутрішнього ринку органічної продукції*

*авторська розробка

Така аграрна структура орієнтована на реалізацію економічних інтересів великих корпоративних формувань; вона не передбачає соціальний розвиток села, паритетний розподіл доходів між секторами, узгодження інтересів різних суб'єктів ринку, держави й населення. Одним із напрямів трансформаційних 
змін може стати освоєння індивідуальними господарствами ринкової німі виробнищтва й переробки органічної продукиії на базі передового європейського досвіду.

Таблиця 1

Частки різних типів господарств у виробництві аграрної продукції в Україні, \%*

\begin{tabular}{|c|c|c|c|c|c|c|c|c|c|}
\hline \multirow{4}{*}{ Види товарів } & \multirow{2}{*}{\multicolumn{3}{|c|}{$\begin{array}{l}\text { Корпоративний } \\
\text { сектор }\end{array}$}} & \multicolumn{6}{|c|}{ Індивідуальний сектор } \\
\hline & & & & \multicolumn{3}{|c|}{ Фермерські господарства } & \multicolumn{3}{|c|}{ Господарства населення } \\
\hline & \multicolumn{9}{|c|}{ Роки } \\
\hline & 2005 & 2010 & 2017 & 2005 & 2010 & 2017 & 2005 & 2010 & 2017 \\
\hline 1. Зернові культури & 65,0 & 63,9 & 63,3 & 10,7 & 12,0 & 14,0 & 24,3 & 24,2 & 22,6 \\
\hline 2.Насіння соняшнику & 63,2 & 64,7 & 67,3 & 15,6 & 17,8 & 19,3 & 21,2 & 17,5 & 13,4 \\
\hline 3.Цукрові буряки (фабричні) & 69,6 & 83,7 & 88,2 & 8,9 & 8,4 & 7,4 & 21,5 & 7,9 & 4,4 \\
\hline 4.Картопля & 0,8 & 1,7 & 1,4 & 0,4 & 0,9 & 0,5 & 98,8 & 97,4 & 98,1 \\
\hline 5. Овочеві культури & 8,6 & 9,3 & 11,5 & 2,1 & 2,6 & 2,9 & 96,3 & 88,1 & 85,5 \\
\hline $\begin{array}{l}\text { 6. Культури плодові та ягід- } \\
\text { ні }\end{array}$ & 11,8 & 16,4 & 12,6 & 0,0 & 0,0 & 3,7 & 88,2 & 83,6 & 83,7 \\
\hline 7. М'ясо всіх видів & 35,9 & 52,8 & 61,5 & 0,9 & 2,3 & 2,5 & 63,2 & 44,9 & 36,0 \\
\hline 8. Молоко всіх видів & 18,1 & 18,7 & 25,0 & 0,7 & 1,0 & 1,9 & 81,2 & 80,3 & 73,1 \\
\hline
\end{tabular}

"розраховано авторами за даними Державної служби статистики України [9]

В умовах глобалізації у виробництві аграрної й харчової продукції отримав розвиток підхід, орієнтований на ведення екологобезпечного й стійкого органічного виробництва, а також мікрофермерства. Такий підхід підтримує ООН як єдино придатний для збереження екології довкілля, відтворення природного біорізноманіття та досягнення продовольчої безпеки теперішнього й майбутнього поколінь [6, с. 27]. Так, у Доповіді Комісії ООН з торгівлі та розвитку наголошено на необхідності глобальних змін в системах харчового сільськогосподарського виробництва й торгівлі. Їх має забезпечити перехід на місцеві продовольчі системи та місцеві дрібні ферми [10].

Процеси зовнішньої інтеграції суттєво впливають на розвиток вітчизняного органічного ринку. Існуюча тенденція зростання обсягів виробництва органічних продуктів за невисоких обсягів внутрішнього споживання (через високу ціну таких товарів) обумовлена збільшенням їх експорту внаслідок зростання зовнішнього попиту, передусім, у Європі. У державах ЄС сегмент органічної сировини не заповнений, щорічний приріст обсягів споживання екотоварів досягає 10 \%. Сьогодні 90-95 \% української органічної продукції експортується, у структурі експорту домінує сировинний напрям, переважно зернові культури. Так, у 2016 р. Україна експортувала 41,45 млн. т зерна, з яких близько 140 тис. тонн - органічного [11].

В Україні розміри сертифікованих органічних господарств різні - від декількох га, як і в більшості країнах Свропи, до декількох тисяч га угідь. Водночас експортні поставки органічної продукції здійснюють підприємства корпоративного сектору, які спроможні сформувати великі товарні партії. Індивідуальні господарства реалізують органічну продукцію або внутрішнім споживачам, або посередни- кам, що формують експортні товарні партії. Необхідно відзначити, що органічна націнка в Свропі складає 50-60 \%, а в Україні - лише 30-40 \%, що значно приваблює трейдерів [6, с. 29]. Відтак, становлення вітчизняного органічного ринку відбувається на основі сировинної моделі розвитку аграрного ринку, що генерує значні втрати доданої вартості і не забезпечує розширене відтворення ресурсів і вирішення ключових проблем відтворювального розвитку суб'єктів ринку. Крім цього, органічний ринок ніби «копіює» структурні дисбаланси у виробництві неорганічної аграрної продукції (див. табл. 1), що у подальшому може привести до експансії органічного сегменту корпоративними структурами та активізації сировинного експорту, що не відповідає економічним інтересам держави, індивідуальних господарств, переробних підприємств і суспільства в цілому.

У Свропі органічне виробництво є дрібнотоварним бізнесом. Враховуючи європейський досвід, 3 метою підтримки фермерських і особистих селянських господарств як формувань, що мають велику соціально-економічну роль для сільських громад, та недопущення структурних дисбалансів у виробництві сільгосппродукції (див. табл. 1), в Україні до органічного виробництва необхідно долучити передусім суб'єктів індивідуального сектору аграрних ринків, використовуючи, зокрема, механізми органічної кооперації, як виробничої, так і обслуговуючої. Дане завдання задекларовано головними формальними інститутами (див. рис. 1). Зайняття ринкової ніші органічного виробництва дозволить індивідуальним господарствам наростити додану вартість, яка $є$ головним ресурсом їх «зеленого» відтворювального розвитку.

Вирішення іншої проблеми - сировинний характер експорту органічної продукції - знаходиться у 
площині розробки та впровадження механізмів стимулювання переробки органічної сировини як в аграрних обслуговуючих кооперативах (переробних і багатофункціональних), так і в переробних підприємствах, зокрема для виробництва вітчизняних продуктів дитячого харчування. У 2017 р. імпорт продуктів дитячого харчування, розфасованих для роздрібної торгівлі (УКТЗЕД 1901100000), склав 5,8 тис. тонн (31,16 млн. дол. США). Порівняно з 2016 р., обсяги імпорту товару у натуральному виразі зросли на $11,5 \%$, у вартісному виразі - на 71,1\%. За період 2006-2017 рр. характерним є стабільно від'ємне сальдо зовнішньої торгівлі, яке у звітному періоді досягло - 27,17 млн. дол. США, збільшившись порівняно 3 2006 р. на 53,1 \% (рис. 2). Основні імпортні товаропотоки продукції дитячого харчування надходять в Україну з Свропи - у 2017 р. три країни (Польща, Швейцарія й Німеччина) забезпечили 70 \% імпорту.

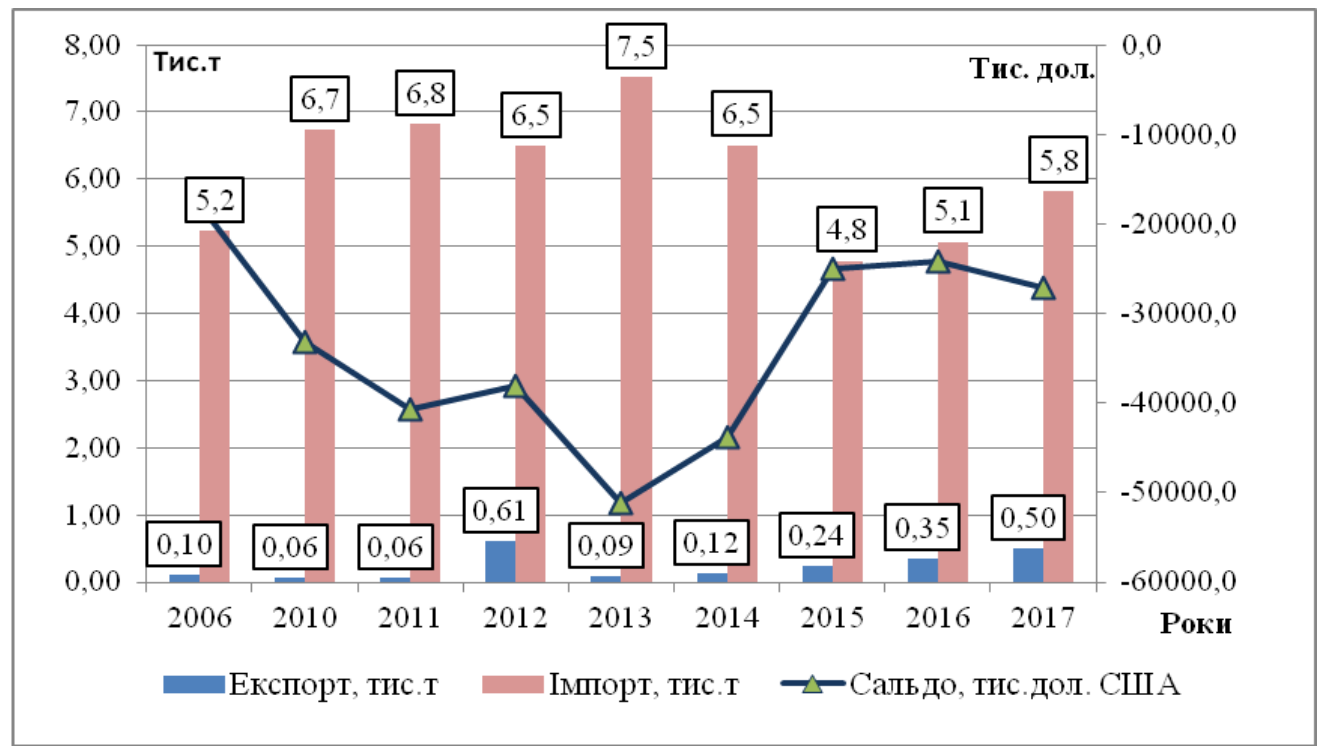

Рис. 2. Обсяги експорту й імпорту продуктів дитячого харчування, розфасованих для роздрібної торгівлі (УКТЗЕД 1901100000)"

* розраховано авторами за даними Державної служби статистики України [12]

У 2017 р. ємність внутрішнього ринку продуктів дитячого харчування, розфасованих для роздрібної торгівлі, досягла 14,73 тис. тонн, збільшившись порівняно з 2011 р. на 20,4%. При цьому частка віт- чизняних продуктів склала 60,5\%, імпортних $39,5 \%$, зменшившись порівняно $з 2011$ р. на $16,3 \%$ (рис. 3).

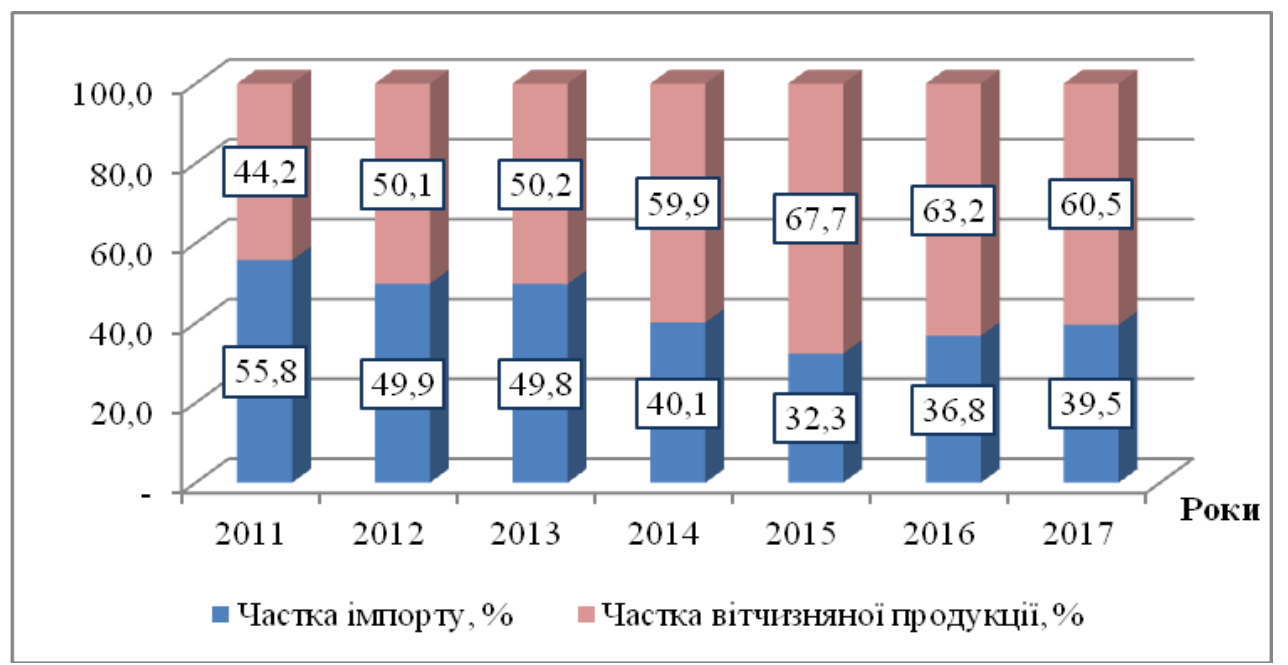

Рис. 3. Частки імпортних й вітчизняних продуктів дитячого харчування, розфасованих для роздрібної торгівлі, на українському ринку *

* розраховано авторами за даними Державної служби статистики України [12] 
Нині в Україні наявний внутрішній попит на продукцію дитячого харчування, який майже на $40 \%$ (5,8 тис. т) задовольняється імпортованим товаром. 3 метою скорочення обсягів імпорту продукції дитячого харчування та стимулювання іiі виробництва в державі із власної органічної сировини, що задекларовано формальними інститутами (див. рис. 1), необхідною є розробка виваженої політики імпортозаміщення та інструментів іï практичного впровадження. Загалом завдання формування внутрішнього попиту на органічну продукцію є багатоаспектним, вимагаючи обгрунтування гнучких механізмів та заходів його досягнення.

Таким чином, виникає необхідність у цілеспрямованому управлінні товарними потоками різних ланок виробничо-логістичного ланцюга органічної продукції для системного вирішення головних проблем розвитку потенційних суб'єктів органічного ринку (див. рис. 1). Відтворювальний підхід, який пропонується використати в ході розбудови керованою державою системи управління органічними товаропотоками, передбачає, 3 одного боку, налагодження i розвиток зв'язків між визначеними суб'єктами за етапами виробничо-логістичного ланцюга, з іншого, узгодження економічних інтересів учасників ринкового процесу відтворення в ході досягнення багаторівневого цільового орієнтиру. Йдеться про стимулювання иільового проиесу відтворення органічної продукиї шляхом керованого формування, поєднання й використання товарних, фінансових та організаційних ресурсів ринкових суб'єктів і держави на засадах узгодження їх економічних інтересів.

Практичне впровадження відтворювального підходу до цілеспрямованого управління товарними потоками різних ланок ланцюга виробничологістичного ланцюга органічної продукції обумовлює необхідність його інституціоналізації, тобто затвердження у законодавчому порядку необхідності та умов взаємодії товарно-фінансових потоків між суб'єктами насіннєвого ринку, індивідуальними господарствами, органічними кооперативами та переробними підприємствами. Формування системи зв'язків між учасниками «зеленого» процесу відтворення повинно відбуватися за активної участі державних i профільних інституцій та 3 використанням селективних регуляторних заходів, особливо на початковому етапі. У ході дослідження авторами розроблено головні складові відтворювального механізму стимулювання розвитку вітчизняного ринку органічної продукції, які представлено в табл. 2.

Головною метою відтворювального механізму стимулювання розвитку органічного виробництва в Україні є формування вітчизняного ринку органічної продукції та внутрішнього попиту на органічну сировину шляхом стимулювання іiі переробки в органічних сільськогосподарських кооперативах та переробних підприємствах для задоволення потреб внутрішнього й зовнішнього ринку у конкурентоспроможній органічній продукції з високою доданою вартістю (див. табл. 2). Основний вектор селективних заходів запропоновано спрямувати на підтримку внутрішнього попиту на украӥнську органічну продукиію.

Таблиця 2

Мета, завдання, селективні заходи й очікувані ефекти відтворювального механізму стимулювання розвитку ринку органічної продукції в Україні

\begin{tabular}{|c|c|}
\hline Складові & Зміст \\
\hline Головна мета & $\begin{array}{l}\text { Формування вітчизняного ринку органічної продукції та внутрішнього попиту на органі- } \\
\text { чну сировину шляхом стимулювання іï переробки в органічних сільськогосподарських } \\
\text { кооперативах та переробних підприємствах для задоволення потреб внутрішнього й зов- } \\
\text { нішнього ринку у конкурентоспроможній органічній продукції з високою доданою варті- } \\
\text { стю }\end{array}$ \\
\hline Завдання & $\begin{array}{l}\text { 1. Залучення шляхом кооперації індивідуальних господарств (фермерських і особистих } \\
\text { господарств) до ринкової ніші органічного виробництва } \\
\text { 2. Підтримка розвитку органічних сільськогосподарських кооперативів, які займаються } \\
\text { переробкою органічної сировини } \\
\text { 3. Забезпечення зайнятості сільського населення, їх добробуту, сталий розвиток сільських } \\
\text { територій, поліпшення родючості грунтів } \\
\text { 4. Стимулювання переробних підприємств, у т.ч. виробництв дитячого харчування, до } \\
\text { переробки вітчизняної органічної сировини } \\
\text { 5. Впровадження ефективних форм взаємодії учасників цільового процесу відтворення } \\
\text { органічної продукції на засадах узгодження їх економічних інтересів } \\
\text { 6. Впровадження екологічно чистих виробництв в агропродовольчу сферу }\end{array}$ \\
\hline Принципи & $\begin{array}{l}\text { 1.Сталого розвитку } \\
\text { 2. Інклюзивності - забезпечення доступу найменш захищених суб’єктів, зокрема, індиві- } \\
\text { дуальних господарств, до ринкової ніші органічного виробництва } \\
\text { 3. Селективності - вибірковість учасників «зеленого» процесу відтворення, заходів дер- } \\
\text { жавної підтримки } \\
\text { 4. Системності, пов'язаності та гнучкості заходів державної підтримки }\end{array}$ \\
\hline
\end{tabular}


Продовження табл.2

\begin{tabular}{|c|c|}
\hline Складові & Зміст \\
\hline $\begin{array}{l}\text { I етап (1-3 рік) } \\
\text { Становлення: } \\
\text { формування ви- } \\
\text { робничих зв'язків } \\
\text { між суб'єктами } \\
\text { ринку, внутріш- } \\
\text { нього попиту на } \\
\text { органічну сиро- } \\
\text { вину }\end{array}$ & $\begin{array}{l}\text { Селективні заходи державної підтримки: } \\
\text { 1. Компенсації втрат виробникам органічної продукції рослинництва за період конверсії } \\
\text { земель } \\
\text { 2.Компенсація } 50 \text { \% вартості органічного насіння культур, виробленого українськими } \\
\text { насіннєвими господарствами, для членів органічних кооперативів. } \\
\text { 3. Погектарні дотації для виробництва органічних культур за умови їх цільового викорис- } \\
\text { тання для переробки або реалізації на внутрішньому ринку. } \\
\text { 4. Залучення бюджетних коштів для будівництва й модернізації потужностей для переро- } \\
\text { бки органічної сировини } \\
\text { 5. Компенсації вартості сертифікації підприємств, що виробляють продукцію дитячого } \\
\text { харчування із органічної сировини, податкові преференції } \\
\text { 6.«Зелені» державні закупівлі органічної продукції } \\
\text { 7. Інформаційне забезпечення процесу формування зв’язків між учасниками «зеленого» } \\
\text { процесу відтворення державними та профільними інституціями }\end{array}$ \\
\hline $\begin{array}{l}\text { II етап (4-5 рік) } \\
\text { Розвиток: } \\
\text { посилення } \\
\text { зв'язків, освоєння } \\
\text { зовнішніх ринків } \\
\text { збуту органічної } \\
\text { продукції }\end{array}$ & $\begin{array}{l}\text { Селективні заходи державної підтримки: } \\
\text { 1.Компенсація } 50 \text { \% вартості органічного насіння культур, виробленого українськими } \\
\text { насіннєвими господарствами, для членів органічних кооперативів. } \\
\text { 2. Залучення бюджетних коштів для будівництва та модернізації потужностей із перероб- } \\
\text { ки органічної продукції } \\
\text { 3. Податкові преференції підприємствам із виробництва органічних продуктів дитячого } \\
\text { харчування } \\
\text { 4.«Зелені» державні закупівлі вітчизняної органічної продукції } \\
\text { 5. Фінансування наукових і маркетингових досліджень } \\
\text { 3. Інформаційне забезпечення розвитку системи зв’язків між суб’єктами }\end{array}$ \\
\hline Очікувані ефекти & $\begin{array}{l}\text { 1. Зростання доданої вартості, підвищення ефективності діяльності органічних індивідуа- } \\
\text { льних господарств аграрного ринку } \\
\text { 2. Підвищення якості життя та добробуту сільського населення, сталий розвиток сільсь- } \\
\text { кого господарства, раціональне використання сільгоспугідь } \\
\text { 3. Зростання обсягів виробництва та споживання органічної продукції в Україні } \\
\text { 4. Зростання частки української продукції дитячого харчування на внутрішньому ринку, } \\
\text { скорочення обсягів імпорту } \\
\text { 5. Розвиток експорту органічної продукції з високою доданою вартістю } \\
\text { 6. Зростання соцвнесків і податкових надходжень від суб'єктів органічного ринку } \\
\text { 7. Сприяння формуванню основ інклюзивної «зеленої» економіки }\end{array}$ \\
\hline
\end{tabular}

* авторська розробка

Досвід провідних країн світу, зокрема Нідерландів, свідчить про ефективність системи субсидування, вектор якої зміщений у бік нарощування попиту на органічну продукцію. Зміна напряму політики із стимулювання органічного виробництва до підтримки розвитку попиту в Нідерландах принесла позитивні результати. Уряд Нідерландів прийняв рішення витрати 50 млн. євро в 2008-2011 рр. для поширення обізнаності та інновацій, а також для стимулювання попиту та покращення виробничих зв'язків в органічному секторі. Виробництво, переробка і логістика тісно пов'язані у цілісний виробничий процес. У Нiдерландах більше ніж 1500 фермерів сертифіковано, 1700 підприємств займаються переробкою органічних продуктів (усе разом це 10 тис. робочих місць), $50 \%$ продукції експортується. Підхід з орієнтацією на попит створив передумови для переходу на вищий щабель розвитку [5, с.386].

Множина завдань відтворювального механізму є багатоплановою і охоплює як економічні, так i соціальні та екологічні цільові орієнтири (див. табл. 2). Перші два завдання орієнтовані на залучення шляхом кооперації індивідуальних господарств до ринкової ніші органічного виробництва та переробки органічної сировини. Його досягнення створить необхідні передумови для сталого розвитку сільських територій, поліпшення родючості грунтів, забезпечення зайнятості і добробуту сільського населення. Орієнтація відтворювального механізму на підтримку внутрішнього попиту формує завдання стимулювання переробних підприємств, у т.ч. виробництв дитячого харчування, до переробки вітчизняної органічної сировини. Практична реалізація перелічених завдань передбачає впровадження ефективних форм взаємодії учасників цільового процесу відтворення органічної продукції на засадах узгодження їх економічних інтересів. Це завдання $є$ найскладнішим, успішність його вирішення залежить від формування розвиненої системи виробничих зв'язків між суб'єктами органічного ринку за активної участі держави.

Механізм, що пропонується, базується на низці принципів, а саме: сталого розвитку, інклюзивності, селективності, системності, пов'язаності та гнучкості заходів державної підтримки (див. табл. 2). 
Принцип інклюзивності передбачає забезпечення доступу найменш захищених суб'єктів, зокрема, індивідуальних господарств, до ринкової ніші органічного виробництва. Принцип селективності акцентує увагу на вибірковості як учасників цільового процесу відтворення органічної продукції, так i заходів державного впливу для досягнення головної мети відтворювального механізму. Принцип системності, пов'язаності та гнучкості заходів державної підтримки передбачає впровадження ефективних регуляторних заходів, моніторинг їх впливу на параметри розвитку органічного ринку та зміну або коригування інструментів впливу за результатами такого моніторингу.

Практичне впровадження відтворювального механізму стимулювання розвитку органічного ринку передбачено в два етапи (див. табл. 2): перший етап охоплює три роки, другий - два роки. На першому етапі шляхом реалізації комплексу селективних заходів державної підтримки відбувається формування виробничих зв'язків між суб'єктами ринку органічної продукції, становлення внутрішнього попиту на органічну сировину, будівництво та модернізацію потужностей для переробки органічної сировини, зростання обсягів випуску продукції дитячого харчування із вітчизняної органічної сировини.

На першому етапі важливим завданням держави є виконання усіх зобов'язань у частині повноти й своєчасності виплат компенсацій і погектарних дотацій для індивідуальних господарств - членів органічних сільськогосподарських кооперативів, а також гарантований збут їх продукції за державним збутовим каналом. При цьому необхідною умовою отримання погектарної дотації $є$ використання виробниками сертифікованого органічного насіння вітчизняного виробництва та реалізація культур за державним або переробним збутовим каналом (однак не посередницьким каналом). Після закінчення першого етапу впровадження відтворювального механізму передбачено зниження розміру погектарних дотацій. В Україні вже існує практика стимулювання аграріїв (у середньому 500 грн./га) для виробництва органічної продукції. У Німеччині обсяг фінансування складає 200400 євро на 1 га сільськогосподарських угідь; після закінчення двох років сума допомоги знижується до 100-200 євро на 1 га. Близько 40 \% у структурі валового доходу екологічних ферм у Німеччині становлять державні субсидії і дотації [4].

3 метою формування внутрішнього попиту на органічну аграрну продукцію доцільним є залучення бюджетних коштів для будівництва (зокрема, в переробних і багатофункціональних кооперативах) та модернізації (в переробних підприємствах) потужностей iз переробки органічної сировини. Для вітчизняних підприємств із випуску дитячого харчування стимулами для впровадження органічного виробництва можуть бути компенсація вартості сертифікації та податкові преференції (див. табл. 2). Селективними заходами стимулювання внутрішнього попиту можуть стати «зелені» державні закупівлі органічної агропродукції, виробленої членами органічних сільськогосподарських кооперативів, та іï наступної реалізації підприємствам дитячого харчування за цінами, нижче ринкових. Такий підхід орієнтований на формування виробничих зв'язків між учасниками «зеленого» процесу відтворення, керований державою рух товаропотоків екопродукції за ланками виробничологістичного ланцюга на засадах узгодження економічних інтересів усіх учасників.

Другий етап впровадження відтворювального механізму передбачає зменшенням обсягів прямого субсидіювання виробників та спрямування бюджетних коштів для фінансування наукових і маркетингових досліджень, необхідних для виходу вітчизняної органічної продукції на зовнішні ринки. Очікується, що становлення внутрішнього попиту, налагодження стабільних зв'язків виробників органічної аграрної продукції з переробними підприємствами, формування сприятливого інституційного середовища створять необхідні передумови для ефективного функціонування органічного ринку в умовах зменшення обсягів державної підтримки. На даному етапі зросте роль інформаційних заходів у становленні виробничих зв'язків між учасниками «зеленого» процесу відтворення. Інформаційне забезпечення розвитку системи виробничих зв'язків повинно здійснюватися за участі як державних (Аграрний фонд, Міністерство аграрної політики та продовольства України, регіональні управління аграрної політики та інші), так і профільних інституцій (Федерація органічного руху, ВГО «Клуб органічного землеробства», Асоціація «БІОЛан Україна» та ін.) шляхом їх тісної співпраці.

Головними очікуваними ефектами від впровадження механізму, що пропонується авторами, $є$ підвищення ефективності органічних індивідуальних господарств та нарощування їх доданої вартості у виробничо-логістичному ланцюгу, зростання обсягів виробництва та споживання органічної продукції в Україні, збільшення частки української продукції дитячого харчування на внутрішньому ринку, скорочення обсягів іiї імпорту, поетапний розвиток експорту вітчизняної органічної продукції з високою доданою вартістю (див. табл. 2). Економічні інтереси держави реалізуються шляхом зростання соціальних внесків і податкових надходжень від суб'єктів органічного ринку. Екологічний ефект від реалізації механізму полягає у впровадженні чистих технологій в агропродовольчу сферу, забезпеченні охорони навколишнього середовища, раціональному використанні сільгоспугідь тощо. Забезпечуючи зайнятість, підвищуючи добробут та якість життя сільського населення, відтворювальний механізм сприятиме формуванню основ інклюзивної «зеленої» економіки в державі (рис. 4). 


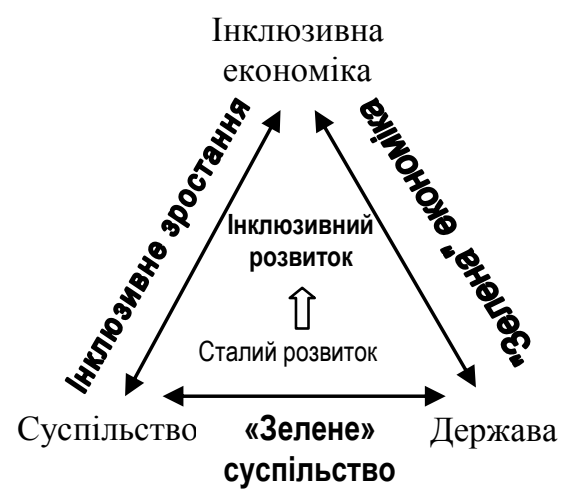

Рис. 4. Взасмозв'язок концепцій сталого та інклюзивного розвитку національної економіки *авторська розробка

Головними параметрами інклюзивного зростання $€$ високі зайнятість і якість життя населення, сприяння забезпеченню соціальної та територіальної згуртованості [13]. Індекс інклюзивного зростання оцінює ступінь поширення позитивних ефектів економічного зростання на всі верстви населення. За останні п’ять років даний індекс для України знизився на $6,8 \%$ (47 місце у рейтингу), що сигналізує про зменшення кількості українців, які отримують вигоди від процесу економічного зростання. Слід відзначити, що у 42 \% країн індекс інклюзивного зростання скоротився, незважаючи на зростання показника ВВП на 1 особу [14], що є свідченням недостатнього впливу держави на процес трансформації економічного розвитку в суспільний прогрес. У цьому світлі особливої значимості набувають відтворювальні регуляторні механізми, у т.ч. запропонований авторами, орієнтовані на досягнення економіко-екологічних та соціальних ефектів у площині становлення інклюзивної «зеленої» економіки.

Висновки та перспективи подальших досліджень. У ході дослідження на базі аналізу положень головних формальних інститутів у сфері розвитку органічного виробництва в Україні обгрунтовано доцільність використання відтворювального підходу до розробки механізму стимулювання розвитку вітчизняного органічного ринку, який орієнтований на системне вирішення економічних проблем розвитку суб'єктів декількох ланок виробничо-логістичного ланцюга шляхом впровадження заходів селективного державного впливу. Відтворювальний підхід передбачає формування керованої державою системи управління органічними товаропотоками та налагодження стійких зв'язків між виробниками (передусім індивідуальними аграрними господарствами) та переробниками (у т.ч. підприємствами 3 виробництва дитячих продуктів харчування) на засадах узгодження їх економічних інтересів.
Головні мета і завдання відтворювального механізму спрямовані на стимулювання цільового процесу відтворення органічної продукції в Україні шляхом керованого формування, поєднання й використання товарно-фінансових та інформаційноорганізаційних ресурсів суб'єктів ринку і держави. Впровадження відтворювального механізму передбачено у два етапи шляхом реалізації комплексу селективних заходів державної підтримки, стимулюючих формування внутрішнього попиту на органічну продукцію. Реалізація механізму генерує комплекс відтворювальних, соціальних, податкових та екологічних ефектів, сумарна дія яких сприяє становленню основ інклюзивного «зеленого» зростання в державі.

Наукова новизна проведеного дослідження полягає в удосконаленні науково-прикладних положень щодо формування механізму стимулювання розвитку вітчизняного органічного ринку на базі відтворювального підходу з акцентом на розвиток внутрішнього попиту та впровадження принципів сталого розвитку, інклюзивності, селективності, системності, взаємопов'язаності й гнучкості заходів державної підтримки. Теоретичне значення результатів дослідження полягає в розвитку концептуальних положень ринкової теорії, «зеленої» економіки в частині обгрунтування інклюзивних інструментів «зеленої» трансформації ринкової економіки, практичне значення визначається можливістю використання авторських розробок державними й регіональними інституціями в ході обгрунтування та впровадження складових відтворювального механізму стимулювання розвитку органічного ринку. Перспективи подальших досліджень полягають у розширенні компонентів відтворювального механізму, заходів державного селективного впливу, обгрунтуванні форм їх реалізації в умовах інституційних трансформацій.

\section{Література}

1. Стратегія розвитку аграрного сектору економіки на період до 2020 р.: затверджена розпорядженням Кабінету Міністрів України від 17.11.2013 № 806-р. База даних «Законодавство України» / КМ України. URL: http://zakon5.rada.gov.ua/laws/show/806-2013-\%D1\%80 (дата звернення 14.01.2019). 
2. Андрєєва Н.М., Козловцева В.А. Організаційно-економічне забезпечення екологічно чистого виробництва в агропромисловій сфері: форми, методи та інструменти // Економіст. 2018. № 9. С. 14-19.

3. Буркинський Б.В. Екологічне чисте виробництво: наукові засади впровадження та розвитку. Вісник Національної академії наук України. 2006. №5. С. 11-17.

4. Вдовиченко А.В. Перспективні напрями державної підтримки органічного сільського господарства в Україні // Агросвіт. 2016. №17. С.44-49.

5. Грановська В.Г. Механізми стимулювання розвитку підприємств органічного сектору: адаптація світового досвіду // Економіка та управління підприємствами. 2017. №9. С. 384-390.

6. Мармуль Л. О., Новак Н.П. Розвиток органічного виробництва в Україні на засадах кооперації. Економіка АПК. 2016. № 9. С. 26-32.

7. Про основні принципи та вимоги до органічного виробництва, обігу та маркування органічної продукції: Закон України від 10.07.2018 № 2496-VII. База даних «Законодавство України» / BP України. URL: http://zakon.rada.gov.ua/laws/show/2496-19 (дата звернення 14.01.2019).

8. Концепція розвитку фермерських господарств та сільськогосподарської кооперації на 2018-2020 роки. Схвалена розпорядженням Кабінету Міністрів України від 13.09.2017 №664-р. База даних «Законодавство України» / KM України. URL: http://zakon0.rada.gov.ua/laws/show/664-2017-\%D1\%80 (дата звернення 14.01.2019).

9. Статистичний щорічник України за 2017 рік / за ред. І.Є.Вернера. Київ: Державна служба статистики України, 2018. 540с.

10. The official site of United Nations Conference on Trade and Development Prosperity for All. URL: http://unctad.org/en/Pages/Home.aspx (date accessed: 14.01.2019).

11. Офіційний сайт Федерації органічного руху в Україні: Органік в Україні. URL: http://organic.com.ua/ru/homepage/2010-01-26-13-42-29 (дата звернення 14.01.2019).

12. Офіційний сайт Державної служби статистики України. Розділ «Зовнішня торгівля окремими видами товарів за країнами світу». URL: http://www.ukrstat.gov.ua/ (дата звернення 14.01.2019).
13. The
2013
Human
Development
Report.
URL:

http://www.undp.org/content/undp/en/home/librarypage/hdr/human-development-report-2013 (date 14.01.2019).
14. Materials
World
Economic
Forum
/ accessed:

https://www3.weforum.org/docs/WEF_Forum_IncGrwth_2017.pdf (date accessed: 14.01.2019).

Стаття надійшла 29.01.2019

Стаття прийнята до друку 12.02.2019

Доступно в мережі Internet 19.03.2019

\author{
Никишина О.В. \\ доктор экономических наук, старший научный сотрудник \\ E-mail: ksenkych@gmail.com \\ ORCID ID: 0000-0002-7172-3551 \\ Муратов О.M. \\ кандидат экономических наук, соискатель \\ отдел рыночных механизмов и структур \\ Институт проблем рынка и экономико-экологических исследований НАН Украины \\ Французский бульвар, 29, г.Одесса, Украина, 65044 \\ E-mail:omuratov45@gmail.com \\ ORCID ID: 0000-0001-5148-4189
}

\title{
ВОСПРОИЗВОДСТВЕННЫЙ МЕХАНИЗМ СТИМУЛИРОВАНИЯ РАЗВИТИЯ УКРАИНСКОГО РЫНКА ОРГАНИЧЕСКОЙ ПРОДУКЦИИ
}

В статье обоснованы природа и компоненты воспроизводственного механизма стимулирования развития отечественного органического рынка. На основе анализа положений стратегических формальных институтов в сфере развития органического производства в Украине обоснована целесообразность использования воспроизводственного подхода к разработке механизма стимулирования развития органического рынка, который ориентирован на системное решение экономических проблем развития субъектов нескольких звеньев производственно-логистической цепи путем внедрения селективных мер государственного воздействия.

Проведена оценка связанных проблем воспроизводственного развития субъектов внутреннего рынка органической продукции, в частности, индивидуальных аграрных хозяйств и предприятий по производству продуктов детского питания. Сделан вывод о том, что становление отечественного органического рынка происходит на основе сырьевой модели развития аграрного рынка с фрормированием ти- 
пичных структурных дисбалансов, присущих рынку неорганической аграрной продукции. Доказана целесообразность разработки и внедрения воспроизводственного механизма стимулирования развития отечественного рынка органической продукции на базе европейской практики, адаптированной к украинским реалиям.

Главная идея воспроизводственного механизма заключается в стимулировании целевого процесса воспроизводства органической продукции в Украине путем управляемого формирования, сочетания и использования товарных, финансовых и организационных ресурсов определенных групп рыночных субъектов и государства. Главной целью воспроизводственного механизма стимулирования развития органического рынка, предлагаемого авторами, является фрормирование внутреннего спроса на органическое сырье путем стимулирования его переработки в органических сельскохозяйственных кооперативах и перерабатывающих предприятиях для удовлетворения потребностей внутреннего и внешнего рынка в конкурентоспособной органической продукции с высокой добавленной стоимостью. Механизм базируется на следующих принципах: устойчивого развития, инклюзивности, селективности; системности, связанности и гибкости мер государственной поддержки. Реализация воспроизводственного механизма предусмотрена в два этапа путем внедрения комплекса селективных мер государственной поддержки, стимулирующих формирование внутреннего спроса на органическую продукцию. Реализация механизма генерирует совокупность воспроизводственных, социальных, налоговых и экологических эффректов, суммарное действие которых способствует становлению основ инклюзивного «зеленого» роста в стране.

Ключевые слова: рынок, органическая продукция, воспроизводственный механизм, институты, субъекты рынка, связи, инклюзивность, меры государственной поддержки.

\author{
Nikishyna 0. \\ Doctor of Economics, Senior Researcher \\ E-mail: ksenkych@gmail.com \\ ORCID ID: 0000-0002-7172-3551 \\ Muratov 0. \\ Candidate of Economics, applicant \\ Department of Market Mechanisms and Structures \\ Institute of Market Problems and Economic \& Ecological Research \\ of National Academy of Sciences of Ukraine \\ Frantsuzskiy boulevard, 29, Odesa, Ukraine, 65044 \\ E-mail:omuratov45@gmail.com \\ ORCID ID: 0000-0001-5148-4189
}

\title{
REPRODUCTION MECHANISM OF STIMULATING DEVELOPMENT UKRAINIAN MARKET OF ORGANIC PRODUCTS
}

The article substantiates the essence and components of the reproduction mechanism for stimulating the development of the domestic organic market. Based on the analysis of the positions of strategic formal institutes in the field of organic production development in Ukraine, the expediency of using a reproduction approach to the development of a mechanism for stimulating the development of the organic market, which focuses on the systematic solution of economic problems of the development of subjects of several links of the production and logistics chain through the implementation of selective measures of the state influence.

The estimation of related problems of reproduction development of the subjects of the internal market of organic products, in particular, individual agricultural enterprises and enterprises for the production of infant food products, has been conducted. It has been concluded that the formation of the domestic organic market takes place on the basis of the raw material model of the agrarian market development with the formation of typical structural imbalances inherent to the market of inorganic agrarian products. The expediency of developing and implementing a reproduction mechanism for stimulating the development of the domestic market of organic products based on European practices adapted to Ukrainian realities has been proved.

The main idea of the reproduction mechanism is to stimulate the target process of reproduction of organic products in Ukraine through the steady formation, combination and use of commodity, financial and organizational resources of certain groups of market subjects and the state. The main objective of the reproduction mechanism for stimulating the development of the organic market proposed by the authors is the formation of domestic demand for organic raw materials by stimulating its processing in organic agricultural cooperatives and processing enterprises to meet the needs of the domestic and foreign markets in competitive organic products with high added value. The mechanism is based on the following principles: sustainable development, inclusiveness, selectivity, systematic manner, connectedness and flexibility of state support measures. Implementation of the reproductive mechanism is envisaged in two stages by introducing a set of selective state 
support measures that stimulate the formation of domestic demand for organic produce. Implementation of the mechanism generates a set of reproductive, social, tax and environmental effects, the total effect of which contributes to the formation of the basis of inclusive "green» growth in the state.

Keywords: market, organic production, reproduction mechanism, institutions, market subjects, communications, inclusiveness, measures of state support.

\section{References}

1. Stratehiia rozvytku ahrarnoho sektoru ekonomiky na period do 2020 r.: Zatverdzhena rozporiadzhenniam Kabinetu Ministriv Ukrainy vid 17.11.2013 № 806-r. (2013). Retrieved January 14, 2019, from http://zakon5.rada.gov.ua/laws/show/806-2013-p

2. Andrieieva, N. M., \& Kozlovtseva, V. A. (2018). Orhanizatsiino-ekonomichne zabezpechennia ekolohichno chystoho vyrobnytstva v ahropromyslovii sferi: Formy, metody ta instrumenty. Ekonomist, (9), 14-19.

3. Burkynskyi, B. V. (2006). Ekolohichne chyste vyrobnytstvo: Naukovi zasady vprovadzhennia ta rozvytku. Visnyk Natsionalnoi Akademii Nauk Ukrainy, (5), 11-17.

4. Vdovychenko, A. V. (2016). Perspektyvni napriamy derzhavnoi pidtrymky orhanichnoho silskoho hospodarstva v Ukraini. Ahrosvit, (17), 44-49.

5. Hranovska, V. H. (2017). Mekhanizmy stymuliuvannia rozvytku pidpryiemstv orhanichnoho sektoru: Adaptatsiia svitovoho dosvidu. Ekonomika Ta Upravlinnia Pidpryiemstvamy, (9), 384-390.

6. Marmul, L. O., \& Novak, N. P. (2016). Rozvytok orhanichnoho vyrobnytstva v Ukraini na zasadakh kooperatsii. Ekonomika APK, (9), 26-32.

7. Pro osnovni pryntsypy ta vymohy do orhanichnoho vyrobnytstva, obihu ta markuvannia orhanichnoi produktsii: Zakon Ukrainy vid 10.07.2018 № 2496-VII. (2018). Retrieved January 14, 2019, from http://zakon.rada.gov.ua/laws/show/2496-19

8. Kontseptsiia rozvytku fermerskykh hospodarstv ta silskohospodarskoi kooperatsii na 2018-2020 roky. Skhvalena rozporiadzhenniam Kabinetu Ministriv Ukrainy vid 13.09.2017 №664-r. (2017). Retrieved January 14, 2019, from http://zakon0.rada.gov.ua/laws/show/664-2017-p

9. Verner, I. Ye. (Ed.). (2018). Statystychnyi shchorichnyk Ukrainy za 2017 rik. Kyiv: Derzhavna sluzhba statystyky Ukrainy.

10. The official site of United Nations Conference on Trade and Development Prosperity for All. Retrieved January 14, 2019, from http://unctad.org/en/Pages/Home.aspx

11. Fitsiinyi sait Federatsii orhanichnoho rukhu v Ukraini: Orhanik v Ukraini. Retrieved January 14, 2019, from http://organic.com.ua/ru/homepage/2010-01-26-13-42-29

12. Ofitsiinyi sait Derzhavnoi sluzhby statystyky Ukrainy. Rozdil «Zovnishnia torhivlia okremymy vydamy tovariv za krainamy svitu». Retrieved January 14, 2019, from http://www.ukrstat.gov.ua/

13. The 2013 Human Development Report (Rep.). (2013, March 14). Retrieved January 14, 2019, from http://www.undp.org/content/undp/en/home/librarypage/hdr/human-development-report-2013

14. Materials World Economic Forum. (2017). Retrieved January 14, 2019, from https://www3.weforum.org/docs/WEF_Forum_IncGrwth_2017.pdf

Received 29 January 2019

Approved 12 February 2019

Available in Internet 19.03.2019

Цитування згідно ДСТУ 8302:2015

Нікішина О.В., Муратов О.М. Відтворювальний механізм стимулювання розвитку українського ринку органічної продукції // Економіка харчової промисловості. 2019. Т.11, вип. 1. С. 37-48; doi: 10.15673/fie.v11i1.1293

Cite as APA style citation

Nikishyna O., \& Muratov O. (2019). Reproduction mechanism of stimulating development Ukrainian market of organic products. Food Industry Economics, 11(1), 37-48; doi: 10.15673/fie.v11i1.1293 